\title{
Evaluation of the Immunomodulatory Activities for Ethyl Acetate Fraction of Cynodon dactylon in Balb/c mice
}

\author{
K. M. Saradha Devi \\ Ph.D Scholar, Department of Biochemistry, Biotechnology and Bioinformatics \\ Avinashilingam University for Women, Coimbatore-43, Tamil Nadu, India \\ Tel: 1-944-250-9040 E-mail: kmsrinithi1981@gmail.com \\ S. Annapoorani \\ Professor, Department of Biochemistry, Biotechnology and Bioinformatics \\ Avinashilingam University for Women, Coimbatore-43, Tamil Nadu, India \\ Tel: 1-944-250-9040 E-mail: annapoorani_bc@avinuty.ac.in \\ Kaliyaperumal Ashokkumar (Corresponding Author) \\ Post Doctoral Fellow, Department of Plant Sciences, University of Saskatchewan \\ 51 Campus Drive, Saskatoon, S7N 5A8, Saskatchewan, Canada \\ Tel: 1-306-881-1014Ｅ-mail: biotech.ashok@gmail.com
}

Received: December 14, 2010 Accepted: January 6, 2011 doi:10.5539/jas.v3n3p182

This research was financed by Department of Biochemistry, Biotechnology and Bioinformatics, Avinashilingam University for Women, Coimbatore, TN, India.

\begin{abstract}
The immunomodulatory properties of ethyl acetate fraction of aqueous extract of Cynodon dactylon have been investigated in experimental animal as Balb/c mice. In this present study, $\mathrm{Balb} / \mathrm{c}$ male mice of 5-7 weeks old $(20-25 \mathrm{~g})$ were maintained under standard laboratory conditions (temperature $25 \pm 2{ }^{\circ} \mathrm{C}$ ) with dark/light cycle (14/10h). The mice were acclimatized to laboratory conditions for 15 days before the commencement of the experiments. The mice were divided into two groups and each group containing 6 mice. The present investigation has revealed that pyrogallol at $50 \mathrm{mg} / \mathrm{kg}$ body weight, produced significant impairment of humoral as well as cell-mediated immune responses. It was observed that daily treatment of $70 \mu$ l of ethyl acetate fraction of Cynodon dactylon $34.3 \mu \mathrm{g}$ polyphenols significantly prevented the immunosuppression caused by pyrogallol. This result suggested that the immunomodulatory effect of ethyl acetate fraction of Cynodon dactylon can be screened by the method in which the immunosuppression was induced by pyrogallol. Hence, we expect that ethyl acetate fraction of aqueous extracts of Cynodon dactylon has strong utility in clinical practice as an effective immunostimulant.
\end{abstract}

Keywords: Balb/c mice, Cynodon dactylon, Ethyl acetate fraction and Immunomodulatory activities

\section{Introduction}

An immunomodulator is a drug used for its effect on the immune system. Since ancient days, plants have been an exemplary source of medicine. Ayurveda and other Indian literature mention the use of plants in treatment of various human ailments. There are many plants, which are having immunostimulatory where as other have immunosuppressant activity (Oladunmoye, 2007). The plant products have long been used as immunomodulators by the traditional healers. The modulation of immune response with the aids of various medicinal plants in order to alleviate certain diseases is an active area of interest. The xenobiotic modulation of immune response is of current scientific interest due to its potential in the treatment of immunocompromised conditions (Thatte and Dahanukar, 1986). Currently available immunosuppressive and immunostimulating agents have major limitations, such as increased risk of infection and inhibition of cells formed by the bone marrow (Diasio and Lo Buglio, 1996). Several ayurvedic medicinal plants are powerful immunomodulators (Devasagayam and Saims, 2002). Recent research has linked their therapeutic actions to their strong antioxidant potential (Govindarajan et al., 2005). Despite their therapeutic importance, very few of them have been 
investigated in detail. Recently studied, immunomodulatory activity of Cynodon dactylon extracts in Swiss albino mice (Santhi and Annapoorani, 2010).

Immunomodulation using plant material can provide an alternative to conventional chemotherapy for a variety of diseases, especially when the host defense mechanism has to be activated under the condition of impaired immune response (Srikumar et al., 2006). Cynodon dactylon is traditionally used as an agent to control diabetes in India (Singh et al., 2007). Literature survey revealed limited scientific investigation has been made in regard to the immunomodulatory activity of Cynodon dactylon leaf fractions. Therefore, the aim of the present study was to "Evaluate the Cynodon dactylon for Immunomodulatory activity in believed experimental model as Balb/c mice".

\section{Materials and Methods}

\subsection{Maintenance of animals}

In this experiment, a total of $12 \mathrm{Balb} / \mathrm{c}$ male mice were used. The current work was carried out after approval by our Institutional animal ethics committee (Registered no. 623/02/b/CPCSEA). The experimental procedure was followed accordance with guidelines on Committee for the Purpose of Control and Supervision of Experiments on Animal Facility (CPCSEA), Government of India. The 5-7 weeks old mice were procured from the animal breeding station, Kerala Agricultural University (KAU), Thrissur, in India. The mice were maintained under standard laboratory conditions (temperature $25 \pm 2^{\circ} \mathrm{C}$ ) with dark/light cycle $(14 / 10 \mathrm{~h})$. They were housed in polypropylene neat cages, bottomed with husk and fed standard pellet diet and water and libitum. The mice were acclimatized to laboratory conditions for 15 days before the commencement of the experiments.

\subsection{Immunomodulatory assay}

\subsubsection{Primary and secondary Humoral immune response}

In this experiment the mice were divided into the two groups and each group containing 6 mice. Group I mice (control mice) were injected with pyrogallol $50 \mathrm{mg} / \mathrm{kg}$ body weight i.p for 7 days with SRBC ( $25 \mu \mathrm{l}$ of serum was serially diluted with $25 \mu$ of PBS i.e. $0.025 \times 10^{9}$ cells). Group II mice were transplanted with pyrogallol 50 $\mathrm{mg} / \mathrm{kg}$ body weight i.p. for 7 days, in $50 \mu \mathrm{l}$ of PBS and also injected with $70 \mu \mathrm{l}$ of ethyl acetate fraction of Cynodon dactylon fraction along with SRBC ( $25 \mu 1$ of serum was serially diluted with $25 \mu 1$ of PBS i.e. $0.025 \mathrm{x}$ $10^{9}$ cells). This work was carried out for a period of 21 days.

On day 13 and 20, blood was withdrawn from the retroorbital plexus of all antigenically challenged rats and then antibody titre from serum was determined. Similar procedure was followed for control also instead of giving plant extract pyrogallol was given for 0-7 days. $25 \mu \mathrm{l}$ of serum was serially diluted with $25 \mu \mathrm{l}$ of phosphate-buffered saline. SRBC $\left(0.025 \times 10^{9}\right.$ cells $)$ were added to each of these dilutions and incubated at $37^{\circ} \mathrm{C}$ for one hour and then examined for hemagglutination (HA) and HA titre. The rank of minimum dilution that exhibited hemagglutination was considered as an antibody titer. The level of antibody titer on day 13 of the experiment was considered as the primary humoral immune response and the on day 20 of the experiment was considered as the secondary humoral immune response.

\subsubsection{Cellular immune response}

The experiment besides mice was divided into the two groups and each group containing 6 mice. Group I mice were injected with pyrogallol $50 \mathrm{mg} / \mathrm{kg}$ body weight i.p for 7 days with SRBC $(25 \mu \mathrm{l}$ of serum was serially diluted with $25 \mu 1$ of PBS i.e. $0.025 \times 10^{9}$ cells). Group II mice were transplanted with pyrogallol $50 \mathrm{mg} / \mathrm{kg}$ body weight i.p. for 7 days and also injected with $70 \mu \mathrm{l}$ of ethyl acetate fraction of Cynodon dactylon along with SRBC $\left(0.05 \mathrm{ml}\right.$ of $5 \times 10^{9)}$ were injected in paw of the mice. It was carried out for a period of 21 days. This was assayed by the footpad reaction method. The edema was induced in the right paw of rats by injecting SRBC $(0.05 \mathrm{ml}$ of $\left.5 \times 10^{9}\right)$ in the sub plantar region on day 20 . The increase in the paw volume in $48 \mathrm{~h}$, i.e. on day 22 was assessed on digital plethysmometer (UGO Basile-7150). The mean percentage increase in paw volume was considered as delayed type of hypersensitivity and as an index of cell-mediated immunity. The volume of the left hind paw, injected similarly with phosphate-buffered saline, served as a control. At the end of the experimental tenure the mice were kept for overnight fasting and then sacrificed. The liver was quickly excised in toto and plunged into sterile, ice-cold saline for removal of blood. The washed organs were blotted dry on sterile filter paper and immediately stored in deep freezer at minus $80^{\circ} \mathrm{C}$. All parameters were analyzed without elapse of time to avoid variations.

\subsection{Statistical analysis}

The experiment results are expressed as means \pm SE. Statistical data were analyzed for Significant difference by one-way analysis of variance followed by Duncan's multiple range tests at a $p<0.05$ was considered statistically significant using SAS software (SAS Version 6, 4th Edn.). 


\section{Results and discussion}

Immunomodulatory agents of plants and animal origin enhance against a pathogen by activating the immune system. In the present preliminary studies revealed that the maximum tolerable dose of pyrogallol was $50 \mathrm{mg} / \mathrm{kg}$, i.p. for 7 days, at which no mortality could be seen up to 30 days. Hence, the experimental group was divided into various subgroups $(\mathrm{n}=6)$ and received a dose of pyrogallol $50 \mathrm{mg} / \mathrm{kg}$ body weight i.p. once daily from Day 1 to 7. In another set of experiment, the immunomodulatory activity of SRBC $50 \mathrm{mg} / \mathrm{kg}$ body weight p.o./daily from Day 1 to Day 22 screened in mice in which immunosuppression was induced by the minimum effective dose of pyrogallol, i.e. $50 \mathrm{mg} / \mathrm{kg}$, as indicated by the earlier part of the experiment. Besides the above treatments, the mice from all the groups received sheep red blood cells (SRBC) $\left(0.5 \times 10^{9}\right.$ cells $/ 100$ g, i.p.) on Day 7 and 13 , as the antigenic material to sensitize them for immunological studies.

The effect of ethyl acetate fraction of Cynodon dactylon in modulating the immunosupression caused by an immunosuppressor pyrogallol injected in Balb/c mice was presented (Figures 1 and 2). The present investigation has revealed that pyrogallol at $50 \mathrm{mg} / \mathrm{kg}$ body weight, produced significant impairment of humoral as well as cell-mediated immune responses. It was observed that daily treatment of $70 \mu 1 / 70 \mu \mathrm{l}$ of ethyl acetate fraction of Cynodon dactylon $34.3 \mu \mathrm{g}$ polyphenols significantly prevented the immunosuppression caused by pyrogallol. This result suggested that the immunomodulatory effects of ethyl acetate fraction of Cynodon dactylon are screened by the method in which the immunosuppression was induced by pyrogallol (Tables 1 and 2).

The documented results had several evidences of the vulnerability of the immune system to the free radical-induced oxidative stress, which indicate that the cellular and humoral components of the immune system are particularly sensitive to increased levels of reactive oxygen species, which may cause premature immunosenescence. The endogenous antioxidant system prevents the deleterious influence of the free radicals on the immune cells and preserves their normal function. Circumstances such as chronic inflammatory diseases, exposure to toxic chemicals, environmental pollutants, radiation, alcohol, and high fat diet, which are known to impair the immune system, are also known to generate free radicals. Impairment in these conditions may thus be subsequent to over utilization of endogenous antioxidants. In view of this, it appears that pyrogallol, which is a strong generator of superoxide radicals, might impair the immune response through oxidative stress. This strong result evidence shows that the ethyl acetate fraction of Cynodon dactylon can be used as a potential source of antioxidant and immunomodulating agent. This finding was on accordance with the findings of Tiwari et al., (2004) in ethanol insoluble fraction of aqueous extract of Tridax procumbens Linn. (TPEIF) and Desai et al., (2002) in dry stem crude extract (DSCE) of Tinospora cordifolia.

\section{Conclusion}

The daily treatment with pyrogallol $50 \mathrm{mg} / \mathrm{kg}$ of body weight of mice for seven days significantly impaired the primary, secondary humoral immune responses and cell - mediated immune response, where as the coadministration of $70 \mu \mathrm{l}$ of ethyl acetate fraction of Cynodon dactylon significantly reverted the immunosuppression, caused by the pyrogallol and thus confirmed the immunomodulatory role. The present study suggested that Cynodon dactylon has shown significant immunomodulatory effect in animals. Hence, we assume that ethyl acetate fraction of Cynodon dactylon promises strong utility in clinical practice as an effective immunostimulant.

\section{References}

Desai, V.R., Kamat, J. P., \& Sainis, K. B. (2002). An immunomodulator from Tinospora cordifolia with antioxidant activity in cell-free systems, Proc. Indian Acad. Sci. (Chem. Sci.)., 114(6): 713-719.

Devasagayam, T.B.A., \& Saims, K. B. (2002). Immunesystemand antioxidants fromIndian medicinal plants. Indian Journal of Experimental Biology, 40, 639-655.

Diasio, R.B., \& Lo Buglio, A.F. (1996). Immunomodulators: immunosuppressive agents and immunostimulants. In: Molinoft, P.B., Ruddon, R.W., Gilman, A.G. (Eds.), The Pharmacological Basis of Therapeutics. McGraw, New York, pp. 1291-1307.

Fimmel., \& Zouboulis, C.C. (2005). Influence of physiological androgen levels on wound healing and immune status in men, Aging Male (PMID 16390741), 8: 166-174.

Govindarajan, R., Vijayakumar, M., \& Pushpangadan, P. (2005). Antioxidant approach to disease management and the role of 'Rasayana' herbs of Ayurveda. Journal of Ethnopharmacology, 99: 165-178.

Oladunmoye, M.K. (2007). The Immunostimulatory Effects of Ethanolic Extract of Assia alata Immuno System of Albino rats Dosed with Staphylococus aureus. Journal of Pharmacology and Technology, 2 (2): 200-204 
Santhi, R., \& Annapoorani, S. (2010). Efficacy of Cynodon dactylon for immunomodulatory activity. Drug Invent. Today, 2(2): 112-114.

Srikumar, R., Jeya, P.N., Manikandan, S., Sathya, N.G., \& Shella, D.R. (2006). Effect of Triphala on oxidative stress and on cell mediated immune response against noise stress in rats. Mol.Cell.Biochem., 283: 67-74.

Singh, S.K., Rai, P.K., Jaiswal, D., \& Watal, G. (2007). Evidence-based Critical Evaluation of Glycemic Potential of Cynodon dactylon. Evidence based Complementary and Alternative Medicine, 1-6.

Thatte, U.M., Dahanukar, S.A. (1986). Ayurveda and contempory scientific thought. Trends in Pharmacological Sciences, 7: 247-249.

Tiwari, U., Bhawna Rastogi., Paramjit Singh., Dinesh, K. S., \& Suresh, P. V. (2004). Immunomodulatory effects of aqueous extract of Tridax procumbens in experimental animals. Journal of Ethnopharmacology, 92(1): 113-119.

Table 1. Antibody titer in the serum of experimental mice administered with and without ethyl acetate fraction of Cynodon dactylon

\begin{tabular}{|l|l|l|l|}
\hline Sl.no. & Treatments & $\begin{array}{l}\text { Primary immune response } \\
\text { (Antibody titre) }\end{array}$ & $\begin{array}{l}\text { Secondary immune response } \\
\text { (Antibody titre) }\end{array}$ \\
\hline 1. & Pyrogallol+SRBC & 8 & 32 \\
\hline 2. & $\begin{array}{l}\text { Pyrogallol+SRBC+ ethylacetate } \\
\text { fraction of Cynodon dactylon }\end{array}$ & 256 & 1024 \\
\hline
\end{tabular}

Table 2. Increase in paw volume of Balb/ c mice administered with and without ethyl acetate fraction of Cynodon dactylon

\begin{tabular}{|l|l|c|}
\hline Sl.no. & Treatments & $\begin{array}{l}\text { Percentage increase in paw volume } \\
\text { in 24 hours }\end{array}$ \\
\hline 1. & Pyrogallol+SRBC & $6.263 \pm 0.3490^{\mathrm{b}}$ \\
\hline 2. & $\begin{array}{l}\text { Pyrogallol + SRBC+ ethylacetate fraction } \\
\text { of Cynodon dactylon }\end{array}$ & $15.667 \pm 0.8725^{\mathrm{a}}$ \\
\hline
\end{tabular}

The values are means \pm SD of six replicates; values are different within the column are significantly different superscripts at $\mathrm{p}<0.05$ by Duncan's multiple range test (DMRT).

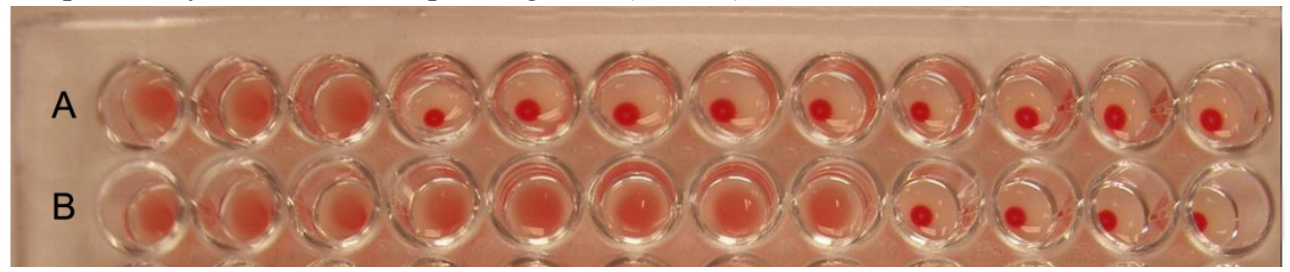

Figure 1. Primary immune response

A) Primary immune response in the serum pyrogallol + SRBC treated mice, B). Primary immune response in the serum pyrogallol $+\mathrm{SRBC}+$ ethyl acetate fraction treated mice.

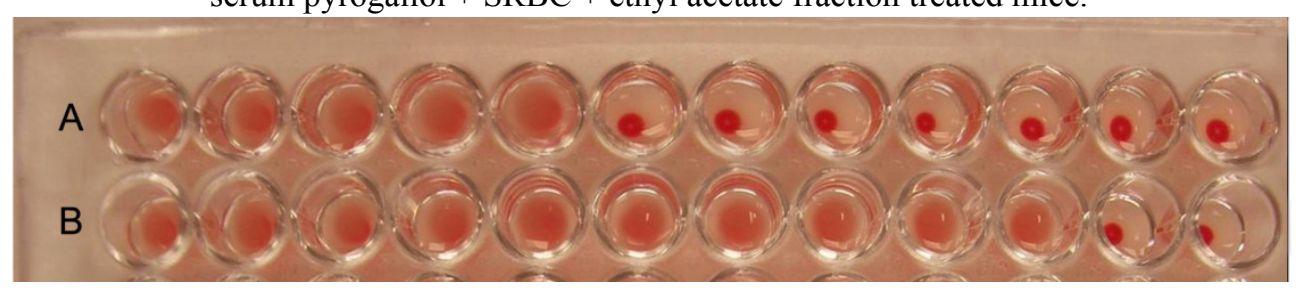

Figure 2. Secondary immune response

A) Secondary immune response in the serum pyrogallol + SRBC treated mice, B) Secondary immune response in the serum pyrogallol $+\mathrm{SRBC}+$ ethyl acetate fraction treated mice. 